\title{
Effect of community based interventions on childhood diarrhea and pneumonia: uptake of treatment modalities and impact on mortality
}

\author{
Jai K Das', Zohra S Lassi', Rehana A Salam¹, Zulfiqar A Bhutta ${ }^{1,2^{*}}$
}

\begin{abstract}
Introduction: Diarrhea and pneumonia are the two leading causes of mortality in children under five. Improvements have occurred over the past two decades but the progress is slow to meet the MDG-4.

Methods: We conducted a systematic review of the randomized controlled trials, quasi-experimental and observational studies to estimate the effect of community based interventions including community case management on the coverage of various commodities and on mortality due to diarrhea and pneumonia. We used a standardized abstraction and grading format and performed meta-analyses for all the relevant outcomes. The estimated effect of community based interventions was determined by applying the standard Child Health Epidemiology Reference Group (CHERG) rules.
\end{abstract}

Results: We included twenty four studies in this review. Community based interventions led to significant rise in care seeking behaviors with 13\% and $9 \%$ increase in care seeking for pneumonia and diarrhea respectively. These interventions were associated with 160\% increase in the use of ORS and $80 \%$ increase in the use of zinc for diarrhea. There was a $75 \%$ decline in the unnecessary use of antibiotics for diarrhea and a $40 \%$ decrease in treatment failure rates for pneumonia. Community case management for diarrhea and pneumonia is associated with a 32\% reduction in pneumonia specific mortality, while the evidence on diarrhea related mortality is weak.

Conclusion: Community based interventions have the potential to scale up care seeking and the use of essential commodities and significantly decrease morbidity and mortality burden due to diarrhea and pneumonia in children under the age of five years.

\section{Introduction}

Approximately 6.9 million deaths of children under five years occurred in 2011 due to preventable and treatable causes [1]. Diarrhea and pneumonia were the two leading causes of mortality accounting for about $29 \%$ of the total burden [2] and more than 95\% of this burden is shared by the 75 Countdown countries. The incidence of diarrhea has declined from 3.4 episodes/child year in 1990 to 2.9 episodes/child year in 2010 [3]. Improvements have been observed, but over a greater span of time [4] and this reduction has unfortunately not been enough to bring us within the reach of the MDG 4, which is to achieve two thirds reduction in the mortality

\footnotetext{
* Correspondence: zulfiqar.bhutta@aku.edu

'Division of Women \& Child Health, The Aga Khan University, Karachi, Pakistan

Full list of author information is available at the end of the article
}

of children under the age of five globally, by the year 2015 [4].

One of the causes for the delay in meeting these targets is the poor access to health facilities and paucity of trained human resources in primary health setups. This deprives the poorest of the populations of simple and effective interventions, like Oral Rehydration Solution (ORS), which has huge potential to save lives. Measures are required to increase awareness among the masses and one such way, is to provide these services through community platforms like home visitation and community based delivery mechanisms. Community Health Workers (CHWs) have been involved in this respect by a few countries especially targeting pneumonia and diarrhea. There has been an increase in programs that train CHWs in poor resource settings to deliver life-saving interventions to children at scale, thus validating the 
quality of the care they deliver $[5,6]$. CHWs in these programs have been assigned the task to educate mothers, diagnose and treat by prescribing antimicrobials and referring complicated cases to first level referral facilities or district hospital. Roesin et al [7] provides evidence that a community based program involving health education by CHWs increased care-seeking for pneumonia in Indonesia and a study from Thailand provides similar evidence [8]. An evaluation of a community-based programme in Matlab, Bangladesh, provides evidence that active case detection and referral to facilities by CHWs can have a beneficial effect on pneumonia mortality [9]. Proper program planning at the initial stage, involving careful hiring, training, intensive field supervision, support and incentives in some cases are the basis of success. In Bangladesh, a study found 87\% agreement between treatments recommended by CHWs and by a study physician for children with suspected pneumonia. Training of these CHWs is the most vital aspect in correct diagnosis and management as shown in Bangladesh BRAC-supported CHWs 'basic' training program which reported that the more the exposure to training, the better was the diagnosis and management of pneumonia $[10,11]$.

Few children in the developing world receive appropriate treatment for diarrhea and pneumonia, even the simple and cost effective interventions like continued feeding, has a coverage of just $39 \%$ and this is even low for ORS [2]. The last decade has been stagnant in terms of the improvement in coverage of essential commodities like ORS and zinc for diarrhea and antibiotics for pneumonia. Recent surveys indicate that worldwide, 78\% of children under-five with symptoms of pneumonia are taken to an appropriate provider; in low-income countries, this coverage is $43 \%$. Antibiotics have an essential role in reducing deaths due to pneumonia and in lowincome countries, less than one-third (29\%) of underfive children with symptoms of pneumonia receive antibiotics [2].

We in this review have estimated the effect of these Community Based Interventions (CBIs) on the care seeking behavior coverage and uptake of essential commodities for diarrhea and pneumonia: ORS, zinc therapy for diarrhea and antibiotics for pneumonia. We have also assessed the impact on negative practices like prescribing unnecessary antibiotics for diarrhea. Previous review by Theodoratou et al [12] estimated that Community Case Management (CCM) of pneumonia could result in a $70 \%$ reduction in mortality from pneumonia in $0-5$-year-old children. We in this review have updated the previous estimate and also estimated the effect of case management on diarrhea mortality. We have reviewed the available literature and evaluated the quality of included studies according to the Child Health
Epidemiology Reference Group (CHERG) adaptation of Grading of Recommendations, Assessments, Development and Education (GRADE) criteria [13].

\section{Methods}

We systematically reviewed all literature published up to Nov 2012 to identify studies describing the effectiveness of CBIs on diarrhea and pneumonia in children less than or equal to 5 years. Following CHERG Systematic Review Guidelines, we searched PubMed, Cochrane Libraries, Embase, and WHO Regional Databases to identify the studies. We included randomized controlled trials, quasi-experimental and observational studies. Additional studies were identified by hand searching references from included studies. No language or date restrictions were applied in the search.

\section{Inclusion criteria}

Studies were included if they reported the effect of CBIs on care seeking behaviors and uptake of essential commodities or case management on morbidity and mortality associated with diarrhea and pneumonia. Studies were included only if a clear case definition of diarrhea and pneumonia were used. The primary outcome measures for CBI were: care seeking rates, use of ORS and zinc for diarrhea, antibiotics use and treatment failure rates for diarrhea and pneumonia and for case management: incidence of moderate or severe episodes of acute lower respiratory infection (ALRI), diarrhea-specific mortality, pneumonia-specific mortality and all-cause mortality.

\section{Abstraction, analysis and summary measure}

For the studies that met the final inclusion criteria, we abstracted data describing study identifiers and context, study design and limitations, intervention specifics and outcome effects into a standardized abstraction form as detailed in the CHERG Systematic Review Guidelines. Each study was assessed and graded according to the CHERG adaptation of the GRADE technique.

\section{Quantitative data synthesis}

We conducted meta-analyses for individual studies and pooled statistics was reported as the relative risk (RR) between the experimental and control groups with 95\% confidence intervals (CI). Mantel-Haenszel pooled RR and corresponding 95\% CI were reported or the DerSimonian-Laird pooled RR and corresponding 95\% CI where there was an unexplained heterogeneity. All analyses were conducted using the software Review Manager 5.1. Heterogeneity was quantified by $\mathrm{Chi}^{2}$ and $\mathrm{I}^{2}$, which can be interpreted as the percentage of the total variation between studies that is attributable to heterogeneity rather than to chance, a low p-value (less than 
0.1 ) or a large chi-squared statistic relative to its degree of freedom and $\mathrm{I}^{2}$ values greater than $50 \%$ were taken as substantial and high heterogeneity. In situations of high heterogeneity, causes were explored by sensitivity analysis and random effect models were used. A subgroup analysis was also performed based on the different age groups. We summarized the evidence by outcome, including qualitative assessments of study quality and quantitative measures, according to the standard guidelines. A grade of "high", "moderate", "low" and "very low" was used for grading the overall evidence indicating the strength of an effect on specific health outcome according to the CHERG Rules for Evidence Review [13].

\section{Results}

We identified 814 papers from search in all databases. After the initial title and abstract screening, 48 full texts were reviewed to identify papers which met the inclusion criteria and had outcomes of our interest. Twenty four papers [14-37] were finally selected for abstraction and analysis (Figure 1). Two studies [15,26] did not report enough data to be included in the meta-analyses. We also included two unpublished trials (Habib et al and Soofi et al) after the author's permission; both of these studies were conducted in Pakistan. All included studies were conducted in Asia or Africa.

\section{Coverage impacts}

In Table 1, we report the quality assessment of studies by outcomes of coverage indicators. The community based interventions significantly improved care seeking for diarrhea and pneumonia by $9 \%$ (RR: $1.09,95 \% \mathrm{CI}$ : $1.06,1.11$ ) and $13 \%$ (RR: $1.13,95 \%$ CI: $1.08,1.18$ ) respectively. The use of ORS increased significantly by 160\% (RR: 2.60, 95\% CI: 1.59, 4.27) (Figure 2) and these CBIs resulted in a 29 folds rise in the use of zinc (RR: 29.79, 95\% CI: $12.33,71.97)$ in the management of diarrhea. The use of antibiotics for diarrhea reduced significantly by $75 \%$ (RR: $0.25,95 \%$ CI: $0.12,0.51$ ), while there was an insignificant impact on use of antibiotics for pneumonia (RR: $1.13,95 \%$ CI: $0.99,1.30$ ), although one study was evaluated for this outcome. The rate of treatment failure for pneumonia also reduced significantly by $40 \%$ (RR: $0.60,95 \%$ CI: $0.51,0.70$ ).

\section{Case management for pneumonia}

In Table 2, we report the quality assessment of studies by outcomes of pneumonia. The estimated impact of CCM on pneumonia-specific mortality in $0-1$ month age group was a $42 \%$ reduction (RR: $0.58,95 \% \mathrm{CI}: 0.44$, 0.77 ), this result was based on four concurrent studies, a $42 \%$ (RR: $0.58,95 \%$ CI: $0.50,0.67$ ) reduction was also estimated for the 0-1 year age group in which nine concurrent and before/after studies were evaluated. In the 1-4 year age group, there was an insignificant $49 \%$ (RR: 0.51, 95\%CI: $0.24,1.07$ ) reduction based on two before/ after studies, while there was a $32 \%$ (RR: 0.68 , 95\%CI: $0.53,0.88)$ reduction in ALRI mortality based on eleven concurrent and before/after studies (Figure 3).

The estimated reduction in all-cause mortality in 0-1 month age group was $27 \%$ (RR: $0.73,95 \%$ CI: 0.65 , 0.82 ), this result was based on five concurrent studies. A $21 \%$ (RR: $0.79,95 \%$ CI: $0.72,0.86$ ) reduction was estimated for the 0-1 year age group in which nine concurrent and before/after studies were evaluated. In the 1-4 years age group, there was a $51 \%$ (RR: $0.49,95 \% \mathrm{CI}$ : 0.34 , $0.76)$ reduction based on two before/after studies, while

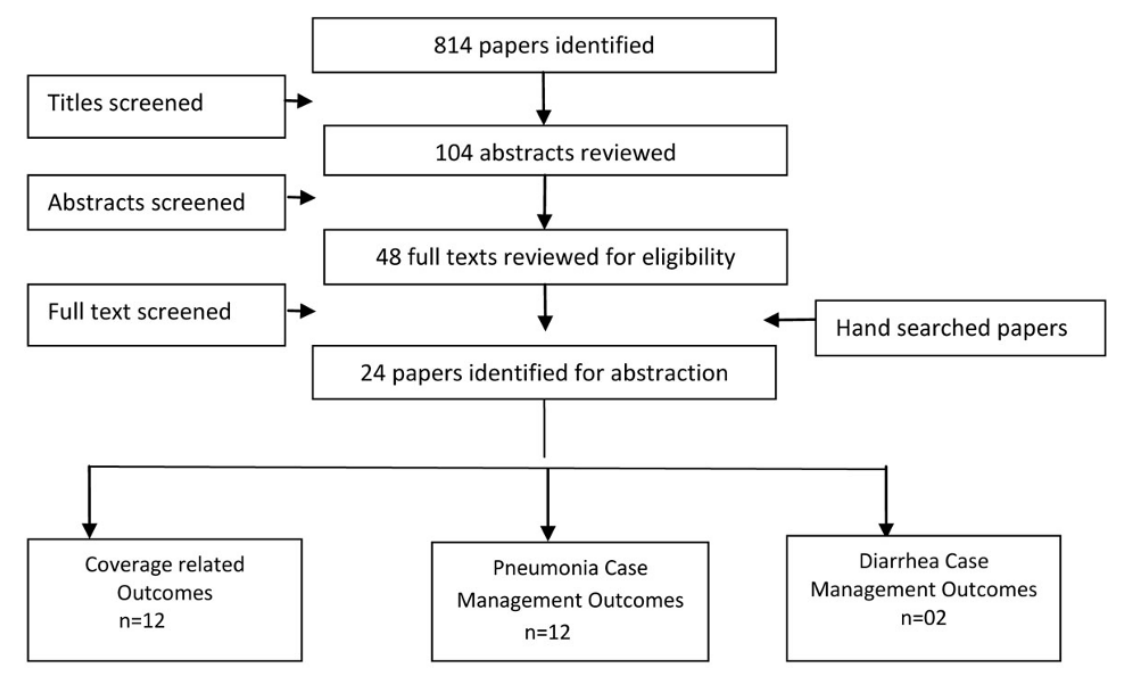

Figure 1 Search strategy flow diagram 
Table 1 Effect of community based interventions on the coverage of commodities/services for diarrhea and pneumonia

\begin{tabular}{|c|c|c|c|c|c|c|c|c|}
\hline \multirow[b]{3}{*}{$\begin{array}{l}\text { No of } \\
\text { studies }\end{array}$} & \multicolumn{5}{|c|}{ Quality Assessment } & \multicolumn{3}{|c|}{ Summary of Findings } \\
\hline & \multicolumn{2}{|c|}{ Directness } & \multicolumn{6}{|l|}{ No of events } \\
\hline & Design & Limitations & Consistency & $\begin{array}{l}\text { Generalizability to } \\
\text { population of interest }\end{array}$ & $\begin{array}{l}\text { Generalizability to } \\
\text { intervention of interest }\end{array}$ & Intervention & Control & $\begin{array}{l}\text { Relative Risk } \\
(95 \% \mathrm{Cl})\end{array}$ \\
\hline \multicolumn{9}{|c|}{ Care seeking rates for Pneumonia: moderate outcome specific quality of evidence } \\
\hline Two & $\begin{array}{l}\text { RCT/ } \\
\text { Quasi }\end{array}$ & $\begin{array}{l}\text { No significant } \\
\text { heterogeneity so a } \\
\text { fixed effect model } \\
\text { used }\end{array}$ & $\begin{array}{l}\text { Both studies } \\
\text { suggest benefit }\end{array}$ & $\begin{array}{l}\text { One study from Asia } \\
\text { and one from Africa }\end{array}$ & $\begin{array}{l}\text { WHO case management } \\
\text { by local health workers }\end{array}$ & 344 & 327 & $\begin{array}{l}1.13[1.08, \\
1.18]\end{array}$ \\
\hline \multicolumn{9}{|c|}{ Care seeking rates for Diarrhea: moderate outcome specific quality of evidence } \\
\hline Four & CRCT & $\begin{array}{l}\text { Significant } \\
\text { heterogeneity so a } \\
\text { random effect model } \\
\text { used }\end{array}$ & $\begin{array}{l}\text { Two studies show } \\
\text { benefit }\end{array}$ & $\begin{array}{l}\text { All studies from } \\
\text { South Asia }\end{array}$ & $\begin{array}{l}\text { Promotion of use of ORS } \\
\text { and zinc by CHWs }\end{array}$ & 3562 & 4691 & $\begin{array}{l}1.09[1.06, \\
1.12]\end{array}$ \\
\hline \multicolumn{9}{|c|}{ ORS use for the management of diarrhea: moderate/low outcome specific quality of evidence } \\
\hline Six & $\begin{array}{l}\text { RCT/ } \\
\text { Quasi }\end{array}$ & $\begin{array}{l}\text { Significant } \\
\text { heterogeneity so a } \\
\text { random effect model } \\
\text { used }\end{array}$ & $\begin{array}{l}\text { All the studies } \\
\text { suggest benefit }\end{array}$ & $\begin{array}{l}\text { All studies are from } \\
\text { Asia }\end{array}$ & $\begin{array}{l}\text { All the studies had } \\
\text { community education } \\
\text { while four studies had } \\
\text { combined intervention of } \\
\text { promotion and zinc } \\
\text { therapy and two had free } \\
\text { distribution of ORS }\end{array}$ & 10446 & 3990 & $\begin{array}{l}2.60[1.59, \\
4.27]\end{array}$ \\
\hline Two & $\begin{array}{l}\text { Before/ } \\
\text { After }\end{array}$ & No major limitation & $\begin{array}{l}\text { All the studies } \\
\text { suggest benefit }\end{array}$ & $\begin{array}{l}\text { Both studies were } \\
\text { from Africa }\end{array}$ & $\begin{array}{l}\text { One study had combined } \\
\text { intervention of } \\
\text { promotion of zinc } \\
\text { therapy }\end{array}$ & 143 & 86 & $\begin{array}{l}1.75[1.48, \\
2.07]\end{array}$ \\
\hline \multicolumn{9}{|c|}{ Use of zinc for the management of diarrhea: moderate outcome specific quality of evidence } \\
\hline Four & CRCT & $\begin{array}{l}\text { Significant } \\
\text { heterogeneity across } \\
\text { studies so a random } \\
\text { effect model used }\end{array}$ & $\begin{array}{l}\text { All Studies } \\
\text { suggest benefit }\end{array}$ & $\begin{array}{l}\text { All studies from } \\
\text { South Asia }\end{array}$ & $\begin{array}{l}\text { CHWs provided } \\
\text { education and promoted } \\
\text { use of ORS and zinc }\end{array}$ & 5554 & 14 & $\begin{array}{l}29.79[12.33 \\
71.97]\end{array}$ \\
\hline \multicolumn{9}{|c|}{ Antibiotic Use for Diarrhea: moderate outcome specific quality of evidence } \\
\hline Four & $\mathrm{CRCT}$ & $\begin{array}{l}\text { Significant } \\
\text { heterogeneity across } \\
\text { studies so a random } \\
\text { effect model used }\end{array}$ & $\begin{array}{l}\text { All studies } \\
\text { suggested a } \\
\text { decline in the use } \\
\text { of antibiotics }\end{array}$ & $\begin{array}{l}\text { All studies from } \\
\text { South Asia }\end{array}$ & $\begin{array}{l}\text { CHWs provided } \\
\text { education and promoted } \\
\text { use of ORS and zinc }\end{array}$ & 639 & 3083 & $\begin{array}{l}0.25[0.12, \\
0.51]\end{array}$ \\
\hline One & $\begin{array}{l}\text { Before/ } \\
\text { After }\end{array}$ & & $\begin{array}{l}\text { Decline in the use } \\
\text { of antibiotics }\end{array}$ & $\begin{array}{l}\text { Study conducted in } \\
\text { Mali }\end{array}$ & $\begin{array}{l}\text { CHWs provided } \\
\text { education and promoted } \\
\text { use of ORS and zinc }\end{array}$ & 104 & 130 & $\begin{array}{l}0.83[0.69, \\
0.99]\end{array}$ \\
\hline \multicolumn{9}{|c|}{ Antibiotic Use for Pneumonia: moderate outcome specific quality of evidence } \\
\hline One & Quasi & & & $\begin{array}{l}\text { Study Conducted in } \\
\text { Uganda }\end{array}$ & $\begin{array}{l}\text { WHO case management } \\
\text { by local health workers }\end{array}$ & 187 & 319 & $\begin{array}{l}1.13[0.99, \\
1.30]\end{array}$ \\
\hline \multicolumn{9}{|c|}{ Treatment Failure Rates for ARI/Pneumonia: moderate outcome specific quality of evidence } \\
\hline Two & CRCT & $\begin{array}{l}\text { No significant } \\
\text { heterogeneity so a } \\
\text { fixed effect model } \\
\text { used }\end{array}$ & $\begin{array}{l}\text { Both studies } \\
\text { suggest benefit }\end{array}$ & $\begin{array}{l}\text { One study from Asia } \\
\text { and one from Africa }\end{array}$ & $\begin{array}{l}\text { WHO case management } \\
\text { by local health workers }\end{array}$ & 228 & 314 & $\begin{array}{l}0.60[0.51, \\
0.70]\end{array}$ \\
\hline
\end{tabular}

there was a $20 \%(\mathrm{RR}: 0.80,95 \% \mathrm{CI}: 0.77,0.83)$ reduction in all-cause mortality based on twelve concurrent and before/after studies.

\section{Case management for diarrhea}

In Table 3, we report the quality assessment of studies by outcomes of diarrhea. There were two studies identified which had evaluated the effect of CCM on diarrhea. The estimated impact on diarrhea specific mortality in the 0-1 year age group was 92\% (RR: 0.08, $95 \% \mathrm{CI}: 0.00,0.87)$ reduction, this result was based on only one before/after study. In the 1-4 years age group, only one before/after study was evaluated and it showed an increase in the diarrhea specific mortality (RR: 2.98, 


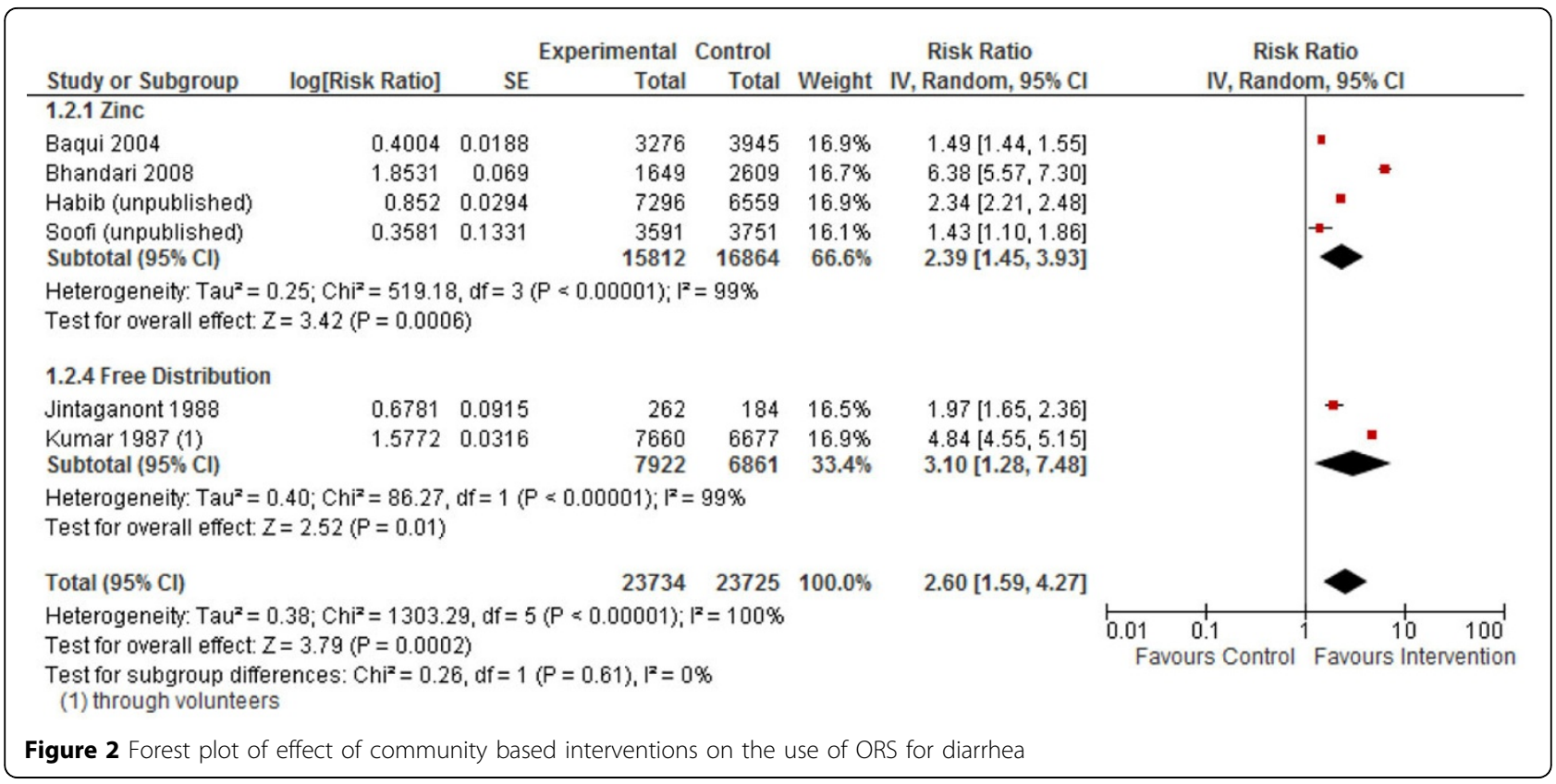

95\%CI: $0.31,28.63)$. While in the $0-4$ years age group, there was a $63 \%$ (RR: $0.37,95 \% \mathrm{CI}$ : $0.15,0.93$ ) reduction based on two concurrent and before/after studies (Figure 4). The effect on all-cause mortality was based on two concurrent and before/after studies and it showed an insignificant 6\% (RR: 0.94, 95\% CI: 0.78, 1.12) reduction.

\section{Recommendation for the LiST model}

Of the outcomes assessed for the effect of CCM on pneumonia and diarrhea in children, we applied the CHERG rules for evidence review. For pneumonia, we applied rule number 2 of effect on cause-specific mortality, to propose that CCM is associated with a $32 \%$ $(12 \%, 47 \%)$ reduction in pneumonia-specific mortality (Figure 5). This estimate is based on analysis of eleven concurrent and before/after studies with 1776 events (Figure 5). For diarrhea the evidence was weak, as there were less than 50 events in cause-specific mortality and the estimate was insignificant for all-cause mortality.

For coverage impacts we propose a $160 \%$ (59\%, 427\%) increase in the use of ORS, this estimate was based on six concurrent studies with 14436 events and a 75\% $(49 \%, 88 \%)$ reduction in the use of antibiotics for diarrhea based on four concurrent studies with 3722 events. We also propose a $80 \%$ increase in the use of zinc for diarrhea; this estimate is based on the percentage difference in the use of zinc amongst the intervention and control groups. For pneumonia related outcomes, we propose $40 \%(30 \%, 49 \%)$ reduction in the treatment failure rates based on two concurrent studies with 542 events.

\section{Discussion}

Community based interventions increase the uptake of services in resource deprived populations with diarrhea and pneumonia. This review further strengthens the evidence shown by previous reviews on the effectiveness of case management.

The CBIs show a significant increase in the uptake of the WHO recommended treatment modalities for diarrhea (ORS and zinc) and at the same time reducing unnecessary use of antibiotics for diarrhea by $75 \%$. For pneumonia, these interventions increased the care seeking behavior by $13 \%$ and the treatment failure rates also reduced by $40 \%$. There was evidence of heterogeneity across the studies in our meta-analyses; however, overall there is consistency in the direction of effect. Our analysis also shows the benefit of case management on pneumonia treatment, as it was associated with a $32 \%$ reduction in pneumonia related mortality and a positive trend was noted in the management of diarrhea.

The models of care were not consistent across studies, with variations in training, diagnostic guidelines and antibiotic prescriptions. But most of the studies have shown significant effects in terms of coverage, access and curative outcomes. This approach also allows the care to be provided near to home, thus averts the need for transportation and saves productive time for the child's care provider. CBI primarily operates through increased access and consequently increasing care-seeking behavior. This approach also highlights the importance of mother's education for the long term sustainability and success of this approach. Although the 
Table 2 Quality assessment of studies of community case management for the treatment of pneumonia

\begin{tabular}{|c|c|c|c|c|c|c|c|c|}
\hline \multirow[b]{3}{*}{$\begin{array}{l}\text { No of } \\
\text { studies }\end{array}$} & \multicolumn{5}{|c|}{ Quality Assessment } & \multicolumn{3}{|c|}{ Summary of Findings } \\
\hline & \multicolumn{2}{|l|}{ Directness } & \multicolumn{6}{|l|}{ No of events } \\
\hline & Design & Limitations & Consistency & $\begin{array}{l}\text { Generalizability } \\
\text { to population } \\
\text { of interest }\end{array}$ & $\begin{array}{l}\text { Generalizability to } \\
\text { intervention of } \\
\text { interest }\end{array}$ & Intervention & Control & $\begin{array}{l}\text { Relative Risk } \\
(95 \% \mathrm{Cl})\end{array}$ \\
\hline \multicolumn{9}{|c|}{ ALRI mortality 0-1 months: moderate outcome specific quality of evidence } \\
\hline Four & Concurrent & No Major & $\begin{array}{l}3 \text { of } 4 \text { studies show } \\
\text { benefit }\end{array}$ & Africa and Asia & $\begin{array}{l}3 \text { of } 4 \text { studies WHO } \\
\text { case management by } \\
\text { local health workers }\end{array}$ & 384 & 686 & $0.58(0.44-0.77)$ \\
\hline \multicolumn{9}{|c|}{ ALRI specific mortality 0-1 year: moderate outcome specific quality of evidence } \\
\hline Six & Concurrent & $\begin{array}{l}\text { No major } \\
\text { limitations }\end{array}$ & $\begin{array}{l}\text { Heterogeneity from } \\
\text { meta-analysis, All } \\
\text { studies show benefit }\end{array}$ & Africa and Asia & $\begin{array}{l}4 \text { of } 6 \text { studies WHO } \\
\text { case management }\end{array}$ & 916 & 1510 & $0.59(0.46-0.75)$ \\
\hline Two & Before/After & $\begin{array}{l}\text { High ALRI } \\
\text { incidence }\end{array}$ & $\begin{array}{l}\text { Heterogeneity from } \\
\text { meta-analysis, All } \\
\text { studies show benefit }\end{array}$ & Asia & $\begin{array}{l}1 \text { of } 2 \text { studies WHO } \\
\text { case management }\end{array}$ & 7 & 34 & $0.36(0.16-0.82)$ \\
\hline Seven & $\begin{array}{l}\text { Concurrent; } \\
\text { before/ after }\end{array}$ & See Above & $\begin{array}{l}\text { Heterogeneity from } \\
\text { meta-analysis, All } \\
\text { studies show benefit }\end{array}$ & Africa and Asia & See Above & 917 & 1522 & $0.57(0.44-0.75)$ \\
\hline Nine & $\begin{array}{l}\text { Concurrent; } \\
\text { before/ after }\end{array}$ & See Above & $\begin{array}{l}\text { Heterogeneity from } \\
\text { meta-analysis, All } \\
\text { studies show benefit }\end{array}$ & Africa and Asia & See Above & 938 & 1569 & $0.58(0.50-0.67)$ \\
\hline \multicolumn{9}{|c|}{ ALRI-specific mortality 1-4 years: low outcome specific quality of evidence } \\
\hline Two & Before/After & $\begin{array}{l}\text { High ALRI } \\
\text { incidence }\end{array}$ & $\begin{array}{l}\text { Both studies show } \\
\text { benefit }\end{array}$ & Asia & $\begin{array}{l}1 \text { of } 2 \text { studies WHO } \\
\text { case management }\end{array}$ & 10 & 24 & $0.51(0.24-1.07)$ \\
\hline \multicolumn{9}{|c|}{ ALRI-specific mortality 0-4 years: moderate outcome specific quality of evidence } \\
\hline Eight & Concurrent & $\begin{array}{l}\text { No major } \\
\text { limitation }\end{array}$ & $\begin{array}{l}\text { Five of eight studies } \\
\text { show benefit }\end{array}$ & Africa and Asia & $\begin{array}{l}6 \text { of } 8 \text { studies WHO } \\
\text { case management }\end{array}$ & 705 & 948 & $0.68[0.53,0.86]$ \\
\hline Six & Before/After & $\begin{array}{l}\text { No major } \\
\text { limitation }\end{array}$ & $\begin{array}{l}\text { Four of six studies } \\
\text { show benefit }\end{array}$ & Africa and Asia & $\begin{array}{l}3 \text { of } 5 \text { studies WHO } \\
\text { case management }\end{array}$ & 220 & 271 & $0.77[0.54,1.08]$ \\
\hline Ten & $\begin{array}{l}\text { Concurrent; } \\
\text { before/ after }\end{array}$ & See Above & $\begin{array}{l}\text { Eight of ten studies } \\
\text { show benefit }\end{array}$ & Africa and Asia & See Above & 724 & 986 & $0.67[0.51,0.88]$ \\
\hline Eleven & $\begin{array}{l}\text { Concurrent; } \\
\text { before/ after }\end{array}$ & See Above & $\begin{array}{l}\text { Nine of eleven studies } \\
\text { show benefit }\end{array}$ & Africa and Asia & See Above & 744 & 1032 & $0.68[0.53,0.88]$ \\
\hline \multicolumn{9}{|c|}{ All cause mortality 0-1months: moderate outcome specific quality of evidence } \\
\hline Five & Concurrent & $\begin{array}{l}\text { No major } \\
\text { limitation }\end{array}$ & $\begin{array}{l}\text { All studies show } \\
\text { benefit }\end{array}$ & Africa and Asia & $\begin{array}{l}4 \text { of } 5 \text { studies WHO } \\
\text { case management }\end{array}$ & 925 & 957 & $0.73(0.65-0.82)$ \\
\hline \multicolumn{9}{|c|}{ All-cause mortality $0-1$ year: moderate outcome specific quality of evidence } \\
\hline Six & Concurrent & $\begin{array}{l}\text { No Major } \\
\text { limitation }\end{array}$ & $\begin{array}{l}\text { All studies show } \\
\text { benefit }\end{array}$ & Africa and Asia & $\begin{array}{l}4 \text { of } 6 \text { studies WHO } \\
\text { case management }\end{array}$ & 2095 & 2487 & $0.78(0.71-0.85)$ \\
\hline Two & Before/After & $\begin{array}{l}\text { High ALRI } \\
\text { incidence }\end{array}$ & $\begin{array}{l}\text { All studies show } \\
\text { benefit }\end{array}$ & Asia only & $\begin{array}{l}1 \text { of } 2 \text { studies WHO } \\
\text { case management }\end{array}$ & 41 & 100 & $0.60(0.42-0.85)$ \\
\hline Seven & $\begin{array}{l}\text { Concurrent; } \\
\text { before/ after }\end{array}$ & See above & $\begin{array}{l}\text { All studies show } \\
\text { benefit }\end{array}$ & Africa and Asia & See above & 2114 & 2524 & $0.77(0.70-0.85)$ \\
\hline Nine & $\begin{array}{l}\text { Concurrent; } \\
\text { before/ after }\end{array}$ & See Above & $\begin{array}{l}\text { All studies show } \\
\text { benefit }\end{array}$ & Africa and Asia & See above & 2230 & 2703 & $0.79(0.72-0.86)$ \\
\hline \multicolumn{9}{|c|}{ All-cause mortality 1-4 years: low outcome specific quality of evidence } \\
\hline Two & Before/After & $\begin{array}{l}\text { High ALRI } \\
\text { incidence }\end{array}$ & $\begin{array}{l}\text { Both studies show } \\
\text { benefit }\end{array}$ & Only Asia & $\begin{array}{l}1 \text { of } 2 \text { studies WHO } \\
\text { case management }\end{array}$ & 43 & 82 & $0.49(0.34-0.70)$ \\
\hline \multicolumn{9}{|c|}{ All-cause mortality 0-4 years: moderate outcome specific quality of evidence } \\
\hline Nine & Concurrent & $\begin{array}{l}\text { No major } \\
\text { limitation }\end{array}$ & $\begin{array}{l}\text { Six studies show } \\
\text { benefit }\end{array}$ & Africa and Asia & $\begin{array}{l}6 \text { of } 9 \text { studies WHO } \\
\text { case management }\end{array}$ & 3115 & 4180 & $0.83[0.73,0.95]$ \\
\hline Six & Before/After & $\begin{array}{l}\text { No major } \\
\text { limitation }\end{array}$ & $\begin{array}{l}\text { Four studies show } \\
\text { benefit }\end{array}$ & Africa and Asia & $\begin{array}{l}3 \text { of } 6 \text { studies WHO } \\
\text { case management }\end{array}$ & 1141 & 1063 & $0.90[0.64,1.26]$ \\
\hline Eleven & $\begin{array}{l}\text { Concurrent; } \\
\text { before/ after }\end{array}$ & $\begin{array}{l}\text { No major } \\
\text { limitation }\end{array}$ & See Above & Africa and Asia & See Above & 3113 & 4401 & $0.80[0.77,0.83]$ \\
\hline Twelve & $\begin{array}{l}\text { Concurrent; } \\
\text { before/ after }\end{array}$ & $\begin{array}{l}\text { No major } \\
\text { limitation }\end{array}$ & See Above & Africa and Asia & See Above & 3214 & 4473 & $0.80[0.77,0.83]$ \\
\hline
\end{tabular}




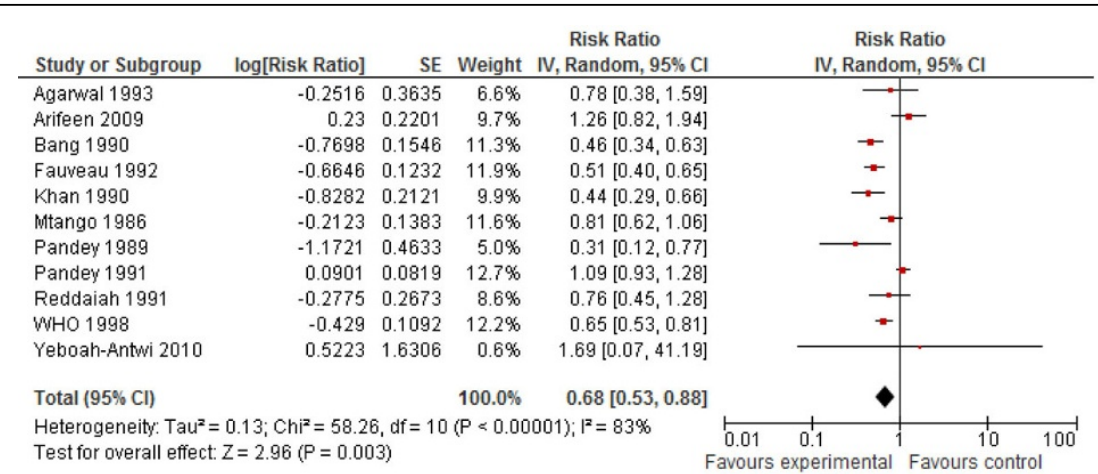

Figure 3 Forest plot of effect of community case management on pneumonia mortality

Table 3 Quality assessment of studies of community case management for the treatment of diarrhea

\begin{tabular}{|c|c|c|c|c|c|c|c|c|}
\hline \multirow[b]{3}{*}{$\begin{array}{l}\text { No of } \\
\text { studies }\end{array}$} & \multicolumn{5}{|c|}{ Quality Assessment } & \multicolumn{3}{|c|}{ Summary of Findings } \\
\hline & \multicolumn{2}{|l|}{ Directness } & \multicolumn{3}{|l|}{ No of events } & \multirow[b]{2}{*}{ Intervention } & \multirow[b]{2}{*}{ Control } & \multirow[b]{2}{*}{$\begin{array}{l}\text { Relative Risk } \\
(95 \% \mathrm{Cl})\end{array}$} \\
\hline & Design & Limitations & Consistency & $\begin{array}{l}\text { Generalizability to } \\
\text { population of interest }\end{array}$ & $\begin{array}{l}\text { Generalizability to } \\
\text { intervention of interest }\end{array}$ & & & \\
\hline \multicolumn{9}{|c|}{ Diarrhea Specific mortality 0-1 years: low outcome specific quality of evidence } \\
\hline One & Before/ After & $\begin{array}{l}\text { No major } \\
\text { limitation }\end{array}$ & & Asia Only & $\begin{array}{l}\text { WHO case management by } \\
\text { local health workers }\end{array}$ & 0 & 11 & $\begin{array}{l}0.05[0.00, \\
0.87]\end{array}$ \\
\hline \multicolumn{9}{|c|}{ Diarrhea Specific mortality 1-4 years: low outcome specific quality of evidence } \\
\hline One & Before/ After & $\begin{array}{l}\text { No major } \\
\text { limitation }\end{array}$ & & Asia Only & $\begin{array}{l}\text { WHO case management by } \\
\text { local health workers }\end{array}$ & 3 & 1 & $\begin{array}{l}2.98[0.31 \\
28.63]\end{array}$ \\
\hline \multicolumn{9}{|c|}{ Diarrhea Specific mortality 0-4 years: moderate outcome specific quality of evidence } \\
\hline One & Concurrent & $\begin{array}{l}\text { No major } \\
\text { limitation }\end{array}$ & & Asia Only & $\begin{array}{l}\text { WHO case management by } \\
\text { local health workers }\end{array}$ & 3 & 8 & $\begin{array}{l}0.56[0.15 \\
2.11]\end{array}$ \\
\hline Two & Before/After & $\begin{array}{l}\text { No major } \\
\text { limitation }\end{array}$ & $\begin{array}{l}\text { Both studies } \\
\text { show benefit }\end{array}$ & Asia Only & $\begin{array}{l}\text { WHO case management by } \\
\text { local health workers }\end{array}$ & 6 & 19 & $\begin{array}{l}0.32[0.13, \\
0.80]\end{array}$ \\
\hline Two & $\begin{array}{l}\text { Concurrent: } \\
\text { Before/After }\end{array}$ & $\begin{array}{l}\text { No major } \\
\text { limitation }\end{array}$ & $\begin{array}{l}\text { Both studies } \\
\text { show benefit }\end{array}$ & Asia Only & $\begin{array}{l}\text { WHO case management by } \\
\text { local health workers }\end{array}$ & 6 & 20 & $\begin{array}{l}0.37[0.15 \\
0.93]\end{array}$ \\
\hline \multicolumn{9}{|c|}{ All-cause mortality 0-4 years: moderate outcome specific quality of evidence } \\
\hline One & Concurrent & $\begin{array}{l}\text { No major } \\
\text { limitation }\end{array}$ & & Asia Only & $\begin{array}{l}\text { WHO case management by } \\
\text { local health workers }\end{array}$ & 157 & 221 & $\begin{array}{l}1.06[0.86, \\
1.30]\end{array}$ \\
\hline Two & Before/After & $\begin{array}{l}\text { No major } \\
\text { limitation }\end{array}$ & $\begin{array}{l}\text { One shows } \\
\text { benefit }\end{array}$ & Asia Only & $\begin{array}{l}\text { WHO case management by } \\
\text { local health workers }\end{array}$ & 194 & 208 & $\begin{array}{l}0.80[0.47, \\
1.35]\end{array}$ \\
\hline Two & $\begin{array}{l}\text { Concurrent; } \\
\text { Before/After }\end{array}$ & $\begin{array}{l}\text { No major } \\
\text { limitation }\end{array}$ & $\begin{array}{l}\text { One shows } \\
\text { benefit }\end{array}$ & Asia Only & $\begin{array}{l}\text { WHO case management by } \\
\text { local health workers }\end{array}$ & 194 & 285 & $\begin{array}{l}0.94[0.78, \\
1.12]\end{array}$ \\
\hline
\end{tabular}

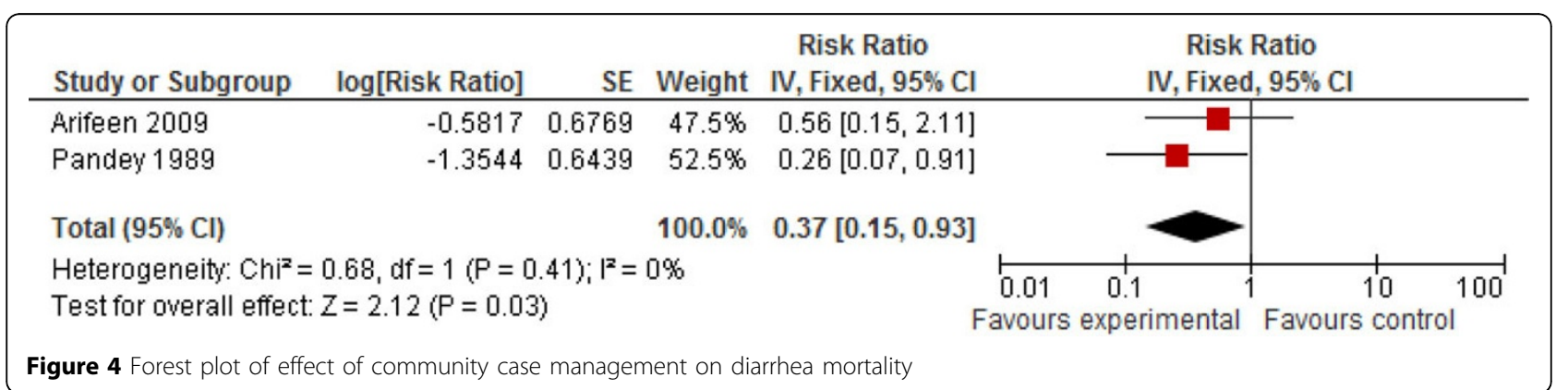


Application of LiST to estimate the effect of community case management on pneumonia mortality

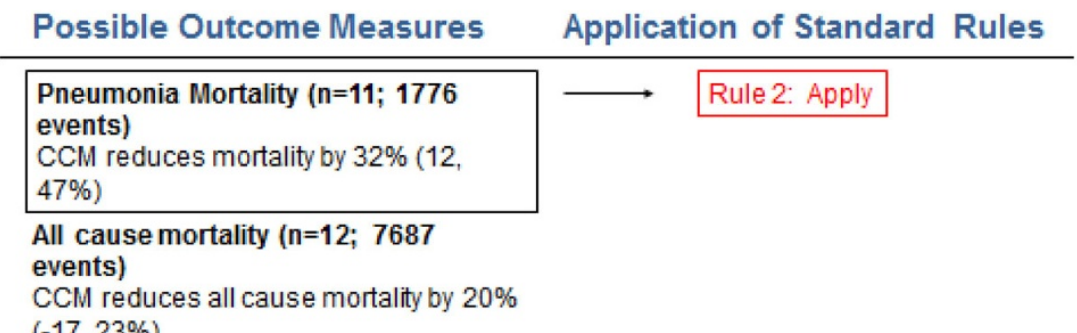

$(-17,23 \%)$

Moderate evidence of mortality reduction: Highly

Plausible

Figure 5 Application of standardized rules for choice of final outcome to estimate effect of community case management on pneumonia mortality

community should be educated, as more awareness amongst care providers would lead to more care seeking, but instant effects from the case management approach should not be expected. Apart from improved access and coverage, these CBIs also lead to improved quality of services and were successful in the early diagnosis and treatment. These programs were also well accepted by the community.

While CHWs can be trained in a minimum of six days; a lot of resources and infrastructure is required for this approach to work at its optimum. The staff and essential commodities at these facilities should be adequate as shortage could discourage care providers from visiting the facility. A study [38] estimated that access to case management is much worse than officially estimated if contribution of physical barriers, staff availability and stock outs were accounted for. It showed that less than $50 \%$ of the population had geographic access (i.e., lived within $10 \mathrm{~km}$ of a facility), and less than $20 \%$ had effective access.

Training of CHWs is the most important component in the correct diagnosis and management. However, correct treatment was poor when there was a long gap (one year) between the training and the follow up [39], so regular refresher trainings are recommended, which would help keep the standards consistent. These CHWs in majority of the programs were not linked to the formal health system of the country and were expected to work as volunteers, which were noticed as a drawback so incentives need to be added to these programs to gain additional grounds. In Pakistan, Lady Health Workers (LHWs) are considered civil servants and given oneyear contracts, hence retention rate is high in these areas. In the first three years of the program, an average of 5.4 per cent of LHWs dropped out per year while in recent years, dropouts have averaged less than 1 per cent per year [40].
Despite of these initial gains, a lot more and sustained effort is required to ensure that children receive appropriate treatment for pneumonia and diarrhea on a larger scale. Barriers such as cultural, economic, and social constraints need to be addressed for the universal uptake. Countries accounting for nearly a quarter of annual global pneumonia mortality, many with low coverage of facility-based treatment do not implement CCM of childhood illnesses. Where CCM is implemented, it often occurs on a limited scale or in pilot projects, commonly supported by international agencies and donors.

Standardization is also needed, in defining case management of childhood illnesses. The global public health community needs an operational definition of this strategy to better describe, monitor and evaluate CCM programs. There is a need for greater accountability in maternal, newborn, and child health programs and this poses new challenges to governments on how to conduct regular assessments of the quality of health services delivered at community level [41].

This approach can reach its full potential if other factors related to child mortality; vaccination, hand washing, hygiene, are also taken care of. While our findings are promising, we suggest areas for further operational research to strengthen CBIs program learning and functioning.

\section{Competing interests}

The authors declare they have no conflict of interest.

\section{Authors' contributions}

Dr. ZAB was responsible for designing the review and co-ordinating the review. JKD, ZL and RAS were responsible for: data collection, screening the search results, screening retrieved papers against inclusion criteria, appraising quality of papers, abstracting data from papers, entering data into RevMan, analysis and interpretation of data and writing the review. ZAB and JKD critically reviewed and modified the manuscript. 


\section{Acknowledgment}

This work was supported in part by a grant from the Bill \& Melinda Gates Foundation (OPP1004060) to Evidence-based landscape analysis on Childhood Diarrheal disorders and development of global consensus on priorities for research and interventions. We would like to acknowledge Lindsey Lenters, who helped us in the search and abstraction of data.

\section{Declarations}

The publication costs for this supplement were funded by a grant from the Bill \& Melinda Gates Foundation to the US Fund for UNICEF (grant 43386 to "Promote evidence-based decision making in designing maternal, neonatal, and child health interventions in low- and middle-income countries"). The Supplement Editor is the principal investigator and lead in the development of the Lives Saved Tool (LiST), supported by grant 43386. He declares that he has no competing interests.

This article has been published as part of BMC Public Health Volume 13 Supplement 3, 2013: The Lives Saved Tool in 2013: new capabilities and applications. The full contents of the supplement are available online at http://www.biomedcentral.com/bmcpublichealth/supplements/13/S3.

\section{Authors' details}

'Division of Women \& Child Health, The Aga Khan University, Karachi, Pakistan. ${ }^{2}$ Global Child Health and Policy, Centre for Global Child Health, The Hospital for Sick Children, Toronto, ON, Canada.

Published: 17 September 2013

\section{References}

1. UNICEF: Levels \& Trends in Child Mortality, Estimates Developed by the UN Inter-agency Group for Child Mortality Estimation. New York, NY: UNICEF; 2012.

2. UNICEF: Pneumonia and diarrhoea, Tackling the deadliest diseases for the world's poorest children. New York, NY: UNICEF; 2012.

3. Fischer Walker $\mathrm{CL}$, Perin J, Aryee MJ, Boschi-Pinto C, Black RE: Diarrhea incidence in low- and middle-income countries in 1990 and 2010: a systematic review. BMC Public Health 2012, 12(1):220.

4. Thompson LM, Bruce N, Eskenazi B, Diaz A, Pope D, Smith KR: Impact of reduced maternal exposures to wood smoke from an introduced chimney stove on newborn birth weight in rural Guatemala. Environmental Health Perspectives 2011, 119(10):1489-1494.

5. Haines A, Sanders D, Lehmann U, Rowe AK, Lawn JE, Jan S, Walker DG, Bhutta Z: Achieving child survival goals: potential contribution of community health workers. Lancet 2007, 369(9579):2121-2131.

6. Rowe AK, de Savigny D, Lanata CF, Victora CG: How can we achieve and maintain high-quality performance of health workers in low-resource settings? Lancet 2005, 366(9490):1026-1035.

7. Roesin R, Sutanto A, Sastra K: ARI Intervention Study in Kediri, Indonesia (A summary of study results). Bulletin of the International Union against Tuberculosis and Lung Disease 1990, 65(4):23.

8. Chongsuvivatwong V, Mo-Suwan L, Tayakkanonta K, Vitsupakoran K, McNeil R: Impacts of Training of Village Health Volunteers in Reduction of Morbidity from Acute Respiratory Infections in Childhood in Southern Thailand. Southeast Asian Journal of Tropical Medicine and Public Health 1996, 27(2):333-338.

9. Ali M, Emch M, Tofail F, Baqui AH: Implications of Health Care Provision on Acute Lower Respiratory Infection Mortality in Bangladeshi Children. Social Science and Medicine 2001, 52(2):267-277.

10. Hadi A: Management of Acute Respiratory Infections by Community Health Volunteers: Experience of Bangladesh Rural Advancement Committee (BRAC). Bulletin of the World Health Organization 2003, 81(3):183-189.

11. Rashid SF, Hadi A, Afsana K, Begum SA: Acute Respiratory Infections in Rural Bangladesh: Cultural understandings, practices and the role of mothers and community health volunteers. Tropical Medicine and International Health 2001, 6(4):249-255.

12. Theodoratou E, Al-Jilaihawi S, Woodward F, Ferguson J, Jhass A, Balliet M, Kolcic I, Sadruddin S, Duke T, Rudan I: The effect of case management on childhood pneumonia mortality in developing countries. International journal of epidemiology 2010, 39(suppl 1):i155-i171.

13. Walker N, Fischer-Walker C, Bryce J, Bahl R, Cousens S: Standards for CHERG reviews of intervention effects on child survival. International journal of epidemiology 2010, 39(suppl 1):i21-i31.
14. Agarwal DK, Bhatia BD, Agarwal KN: Simple approach to acute respiratory infection in rural under five children. Indian Pediatr 1993, 30(5):629-635.

15. Ali M, Emch M, Tofail F, Baqui AH: Implications of health care provision on acute lower respiratory infection mortality in Bangladeshi children. Soc Sci Med 2001, 52(2):267-277.

16. Arifeen SE, Hoque DM, Akter T, Rahman M, Hoque ME, Begum K, Chowdhury EK, Khan R, Blum LS, Ahmed S: Effect of the Integrated Management of Childhood IIIness strategy on childhood mortality and nutrition in a rural area in Bangladesh: a cluster randomised trial. Lancet 2009, 374(9687):393-403.

17. Bang AT, Bang RA, Tale O, Sontakke P, Solanki J, Wargantiwar R, Kelzarkar P: Reduction in pneumonia mortality and total childhood mortality by means of community-based intervention trial in Gadchiroli, India. Lancet 1990, 336(8709):201-206

18. Datta N, Kumar V, Kumar L, Singhi S: Application of case management to the control of acute respiratory infections in low-birth-weight infants: a feasibility study. Bulletin of the World Health Organization 1987, 65(1):77.

19. Fauveau V, Stewart MK, Chakraborty J, Khan SA: Impact on mortality of a community-based programme to control acute lower respiratory tract infections. Bulletin of the World Health Organization 1992, 70(1):109.

20. Khan AJ, Khan JA, Akbar M, Addiss DG: Acute respiratory infections in children: a case management intervention in Abbottabad District, Pakistan. Bulletin of the World Health Organization 1990, 68(5):577.

21. Lye MS, Nair RC, Choo KE, Kaur H, Lai KPF: Acute respiratory tract infection: a community-based intervention study in Malaysia. Journal of tropical pediatrics 1996, 42(3):138.

22. Mtango FDE, Neuvians D: Acute respiratory infections in children under five years. Control project in Bagamoyo District, Tanzania. Transactions of the Royal Society of Tropical Medicine and Hygiene 1986, 80(6):851-858.

23. Pandey MR, Daulaire NMP, Starbuck ES, Houston RM, McPherson K: Reduction in total under-five mortality in western Nepal through community-based antimicrobial treatment of pneumonia. Lancet 1991, 338(8773):993-997.

24. Pandey MR, Sharma PR, Gubhaju BB, Shakya GM, Neupane RP, Gautam A, Shrestha IB: Impact of a pilot acute respiratory infection (ARI) control programme in a rural community of the hill region of Nepal. Annals of tropical paediatrics 1989, 9(4):212.

25. Reddaiah VP, Kapoor SK: Effectiveness of ARI control strategy on underfive mortality. Indian journal of pediatrics 1991, 58(1):123-130.

26. Shimouchi A, Yaohua D, Zhonghan Z, Rabukawaqa VB: Effectiveness of control programs for pneumonia among children in China and Fiji. Clinical infectious diseases 1995, 21(Supplement 3):S213.

27. Kielmann AA, Taylor CE, DeSweemer C, Uberoi IS, Takulia HS, Masih N Vohra S: The Narangwal experiment on interactions of nutrition and infections : Il. Morbidity and mortality effects. Indian J Med Res 1978, 68(Suppl):21-41.

28. World Health Organisation, Case Management of Acute Respiratory Infections in Children Intervention Studies, WHO/ARI/88.2. WHO/ARI/882 Geneva: WHO; 1998.

29. Yeboah-Antwi K, Pilingana P, Macleod WB, Semrau K, Siazeele K, Kalesha P, Hamainza B, Seidenberg P, Mazimba A, Sabin L: Community case management of fever due to malaria and pneumonia in children under five in Zambia: a cluster randomized controlled trial. PLoS Medicine 2010, 7(9):e1000340.

30. Baqui AH, Black RE, El Arifeen S, Yunus M, Zaman K, Begum N, Roess AA, Santosham M: Zinc therapy for diarrhoea increased the use of oral rehydration therapy and reduced the use of antibiotics in Bangladeshi children. J Health Popul Nutr 2004, 22(4):440-442.

31. Bhandari N, Mazumder S, Taneja S, Dube B, Agarwal RC, Mahalanabis D, Fontaine O, Black RE, Bhan MK: Effectiveness of zinc supplementation plus oral rehydration salts compared with oral rehydration salts alone as a treatment for acute diarrhea in a primary care setting: a cluster randomized trial. Pediatrics 2008, 121(5):e1279-e1285.

32. Winch PJ, Doumbia S, Kante M, Male AD, Swedberg E, Gilroy KE, Ellis AA, Cisse G, Sidibe B: Differential community response to introduction of zinc for childhood diarrhea and combination therapy for malaria in southern Mali. The Journal of nutrition 2008, 138(3):642-645.

33. Edward A, Ernst P, Taylor C, Becker S, Mazive E, Perry H: Examining the evidence of under-five mortality reduction in a community-based programme in Gaza, Mozambique. Transactions of the Royal Society of Tropical Medicine and Hygiene 2007, 101(8):814-822. 
34. Kumar V, Kumar R, Datta N: Oral rehydration therapy in reducing diarrhoea-related mortality in rural India. J Diarrhoeal Dis Res 1987, 5(3):159-164.

35. Jintaganont $P$, Stoeckel J, Butaras $S$ : The impact of an oral rehydration therapy program in Southern Thailand. American journal of public health 1988, 78(10):1302-1304.

36. Kalyango JN, Lindstrand A, Rutebemberwa E, Ssali S, Kadobera D, Karamagi C, Peterson S, Alfven T: Increased use of community medicine distributors and rational use of drugs in children less than five years of age in Uganda caused by integrated community case management of fever. The American Journal of Tropical Medicine and Hygiene 2012, 87(5 Suppl):36-45.

37. Soofi S, Ahmed S, Fox MP, MacLeod WB, Thea DM, Qazi SA, Bhutta ZA: Effectiveness of community case management of severe pneumonia with oral amoxicillin in children aged 2-59 months in Matiari district, rural Pakistan: a cluster-randomised controlled trial. Lancet 2012, 379(9817):729-737.

38. Guenther T, Sadruddin S, Chimuna T, Sichamba B, Yeboah-Antwi K, Diakite B, Modibo B, Swedberg E, Marsh DR: Beyond distance: an approach to measure effective access to case management for sick children in Africa. The American Journal of Tropical Medicine and Hygiene 2012, 87(5 Suppl):77-84.

39. Chaudhary N, Mohanty PN, Sharma M: Integrated management of childhood illness (IMCI) follow-up of basic health workers. Indian journal of pediatrics 2005, 72(9):735-739.

40. Oxford Policy Management: 'Pakistan: Evaluation of the Prime Minister's Programme for Family Planning and Primary Health Care: Interim Report'. Oxford Policy Management, Oxford 2000.

41. WHO: Keeping Promises, Measuring Results, Commission on information and accountability for women's and children's health. Geneva: World Health Organization; 2011.

doi:10.1186/1471-2458-13-S3-S29

Cite this article as: Das et al.: Effect of community based interventions on childhood diarrhea and pneumonia: uptake of treatment modalities and impact on mortality. BMC Public Health 2013 13(Suppl 3):S29.

\section{Submit your next manuscript to BioMed Central and take full advantage of:}

- Convenient online submission

- Thorough peer review

- No space constraints or color figure charges

- Immediate publication on acceptance

- Inclusion in PubMed, CAS, Scopus and Google Scholar

- Research which is freely available for redistribution

Submit your manuscript at www.biomedcentral.com/submit
Biomed Central 